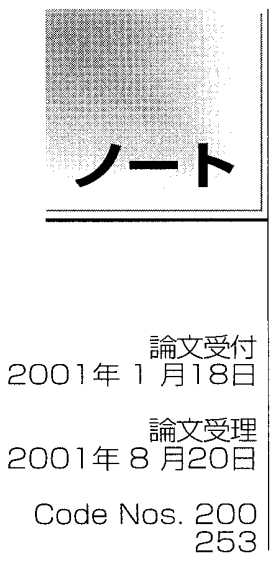

\section{撮像管を用いたI.I.-DR消化管造影における digital值補償フィルタの検討}

\author{
井ノ上信一・松本光弘・小縣裕二1）
}

大阪大学医学部附属病院放射線部

1 ) 大阪大学医学部医用物理学講座

\section{1. 目 的}

近年，X線診断撮影装置のdigital化が進み，消化管 造影検査にもdigital radiography (以下, DR) 装置が導 入されている1ー3). 当院においてもpicture archiving and communication system (PACS) を構築するためimage intensifier(以下, I.I.) DRシステムのX線TVを用い ている4). I.I.-DRは従来のscreen/film(以下，S/F)系に 比べX線検出効率が高く, 被曝低減が可能である5 画質は受光系に撮像管を用いたシステムでは空間分解 能がS/F系に比べ劣るが, 受光系をcharge coupled device (以下, $\mathrm{CCD}$ )カメラに変え ${ }^{6)}$, コらにそのCCD も
100万画素から400万画素に変えることで画質が大幅に 向上し，S/F系と同等の画質が得られたという報告も ある7).しかしI.I.-DRは，S/F系に比べダイナミック レンジが狭いため体厚変化掞よび管腔臟器内の空気含 有量によって透過X線量の差が大きくなるとdigital值 がサチュレートすることが日常的に起こりやすくな る。サチュレートするとその部分のデータが一定とな り，画像処理を行っても画像として成立しない，本論 文ではこのサチュレートの解決策として，S/F系で用 いられている濃度補償フィルタの導入を検討した．S/ F系における濃度補償フィルタの検討抢よびDRによる

\title{
Evaluation of Compensation Filter in I.I.-DR Gastrointestinal Examination Using Image Pick-up Tube
}

SHINICHI INOUE, MITSUHIRO MATSUMOTO, and YUJI OGATA')

Department of Radiology, Osaka university hospital

1) Department of Medical Physics Faculty of Medicine Osaka University

Received Jan. 18 2001; Revision accepted Aug. 20, 2001; Code Nos. 200, 253

\section{Summary}

We have especially the thing which experiences daily and which digital value does saturate by the difference of patient, and the air content of internal organs, at the time of I.I.-DR gastrointestinal examination. In order to compensate digital value of those parts, the compensation filter by the remote operation formula was examined. The quality of the material of the created filter determined thickness and form from change of digital value when changing thickness, and a dose using aluminum. The image which carried out saturate as a result of analyzing this 500 images decreased to $15 \%$ to $3 \%$. Moreover, the total skin dose decreased on the same photography conditions, and was almost equivalent in the time of phototimer use. The part not conventionally materialized as an image for saturation has been improved by using a compensation filter for gastrointestinal examination, and it was enabled to obtain a useful picture clinically.

Key words: Digital radiography, Added filter, Exposure dose 
被曝低減を目的とした付加フィルタについてはさまざ まな報告がある8 11)。しかしDRによるdigital值を補償 するための補償フィル夕を検討した報告はない.そこ でわれわれは撮像管を用いたI.I.-DR消化管造影検査 の診断能を向上させるための一方法として遠隔操作式 の可動補償フィルタを検討したので報告する.

\section{2. 使用機器}

使用機器は以下の通りである。

DR装置：DR-2000H

画素数 $1,024 \times 1,024$ bit数12

X線透視撮影：TU-230XB

X線高電圧装置：GHF-S2-158H

X線TV：XTV-2000(ダイオードガンサチコン)

(以上，株式会社日立メディコ製)

線量計：9015型放射線モニ夕10X5-6(6cc)

(ラドカル社製)

また撮像管タイプとCCDタイプの入出力特性を比較 するため次の装置を用いた。

DR装置：DDX-100A

画素数 $1,024 \times 1,024$ bit数 12

$\mathrm{X}$ 線透視撮影：DBA-100A

$\mathrm{X}$ 線高電圧装置：KXO-80N

X線TV：MTV-250A (CCD)

（以上，株式会社東芝メディカル製）

\section{3. 方 法}

\section{3-1 臨床画像のdigital值の検討}

1998年11月～1999年 1 月の期間，注腸検査で得ら れたハードコピーから500画像をランダムに選択し た.これらの画像でX線吸収の違いによりハレーショ ンを起こし, digital值がサチュレートした画像につい て装置付属の画像解析プログラムによりdigital值解析 を行った. ROIは $100 \times 100$ ピクセルとし, サチュレー トした部分のdigital值を測定し, その平均值を求め た。

\section{3-2 入出力特性の検討}

撮像管とCCDのダイナミックレンジを比較するため I.I.-DRシステムの入出力特性を測定した。臨床に即

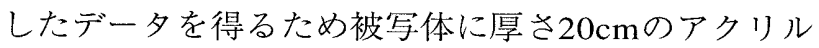
ファントムを用いた。照射野は1 $15 \times 15 \mathrm{~cm}$ と, 均一 照射を行った。撮影条件は管電圧 $90 \mathrm{kV一}$ 一定とし, $\mathrm{mAs}$ 值を $10 \mathrm{mAs}$ からタイマを 2 倍ずつ変化させ，装置 の出力限界まで撮影した。 これらの画像を画像解析プ ログラムにより，digital值を計測した。 ROIは100× 100 ピクセルとした。 それと同時にアクリルファント ムの表面線量を線量計を用い，測定した。線量值をり

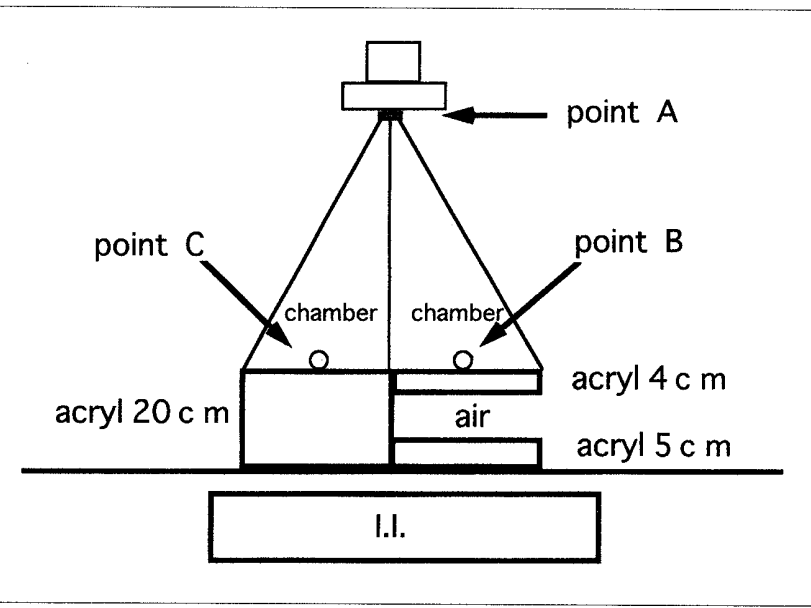

Fig. 1 Measurement arrangement.

ファレンスとしたdigital值の関係を入出力特性とし た。

\section{3-3 フィルタの厚さ, 形状の検討}

フィルタの厚さ, 形状を検討するためFig. 10よう に左半分はアクリル $20 \mathrm{~cm}$, 右半分はアクリル $4 \mathrm{~cm}$ と $5 \mathrm{~cm}$ とし，その中間に空気層 $(11 \mathrm{~cm})$ を設定したファン トムを使用した。フィルタの材質にはアルミニウム (以下，Al）を用い，Fig. 1のA点(X線管球直下)の位置 でAl厚を 1 〜 $10 \mathrm{~mm}$ まで変化させ曝射した。得られた データから3-2と同様にB点(ファントム中央部)での digital值を計測した。また同時にAl厚を変化させたと きのB点での線量変化を線量計を用いて測定した。こ れらの結果から最適なAlフィルタの厚さ，形状を決定 した.

\section{4. 結 果}

\section{4-1 臨床画像の検討}

注腸検査の臨床画像500画像で, digital值がサチュ レートした部分が含まれる画像が74例(約15\%)あっ た。またこれらの画像のdigital值は充盈部で平均 $3,615 \pm 176.7$, 二重造影部で平均 $2,698 \pm 234.9$, 空気層

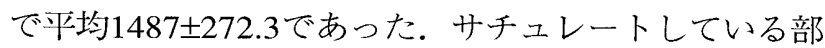
分は10以下であった。このDR装置の場合，濃度階調 12bit 4,096階調であるが，白黒を反転させているため digital值の昇降順が逆になっているため，値の小さい ほうが，濃度が高いことを表している。

\section{4-2 入出力特性の検討}

Fig. 2に当院のI.I.-DRシステムの入出力特性を示 す. Fig. 2から入出力特性は撮像管タイプよりもCCD タイプのほうがダイナミックレンジは広く, digital值 1,000〜3,000の範囲で平均して約 2 倍であった。 


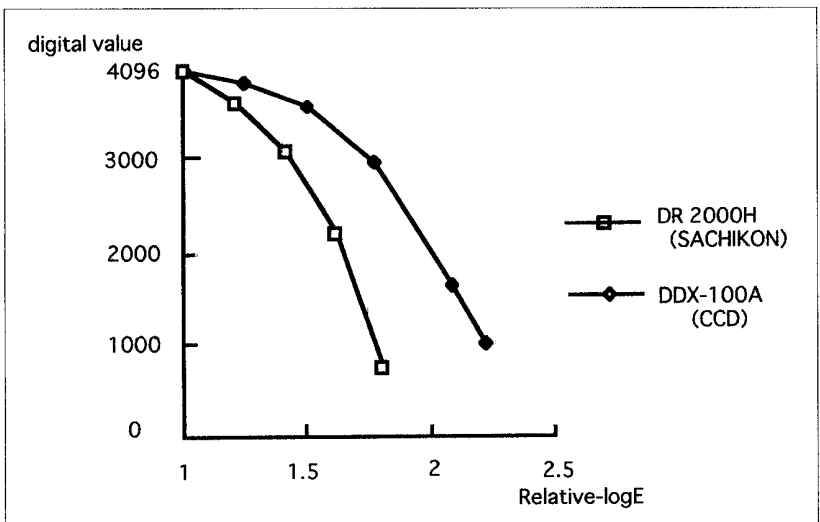

Fig. 2 Characteristic curve of digital value and dose by 1.I.DR system.

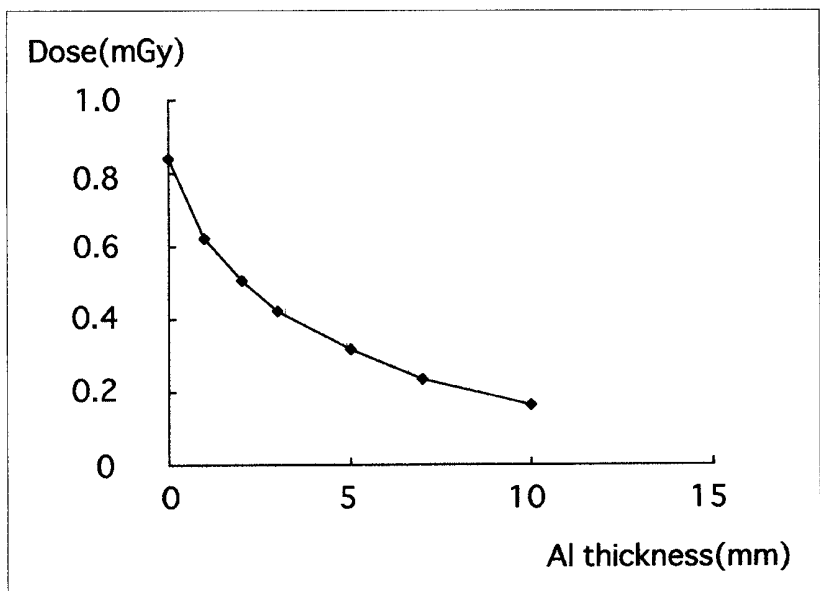

Fig. 4 Relation of aluminum thickness and dose.

4-3 フィルタの厚さ, 形状の検討

Alの厚さを 1 ～10mm まで変化させたときのdigital值 の変化をFig. 3 に示す. 約Al厚 $2 \mathrm{~mm}$ まではdigital值に 変化がなく約 $\mathrm{Al}$ 厚 $3 \mathrm{~mm}$ から直線的に変化した。 $\mathrm{Al}$ 厚 $7 \mathrm{~mm}$ でdigital值が約1,200まで改善された。すなわち $\mathrm{Al}$ 厚 $7 \mathrm{~mm}$ を付加することによって4-1で検討した空気 層のdigital值に近づいたことを示している。次に同様 にAl厚を変化させたときの線量の変化をFig. 4に示 す。線量はAIの減弱を反映し，Al厚の増加とともに指 数関数的に変化した。 $\mathrm{Al}$ 厚 $5 \mathrm{~mm}$ で約 $60 \%$ 減弱してい る. Fig. 5は光子減弱計数データブック ${ }^{12)}$ からAlの減 弱係数と人体組織の減弱係数の関係を示す. X線エネ ルギーは，管電圧90～100kVに相当する $35 \mathrm{keV} て ゙$ 行っ た。この場合 $\mathrm{Al}$ 厚 $5 \mathrm{~mm}$ は人体組織の約 $3.5 \mathrm{~cm}, \mathrm{Al}$ 厚 $7 \mathrm{~mm}$ は約 $5 \mathrm{~cm}$ に相当している。これらの結果から補償 フィルタの厚さを検討した。サチュレートしたdigital 值を改善させるためにはFig. 3のようにAl厚を厚くす るほどよいが, Fig. 4の線量の変化拉よびFig. 5の減弱 係数の関係からAl厚は約 5〜7m付加すればよい. 形 状は左右端に少量のハレーション領域が発生する場合

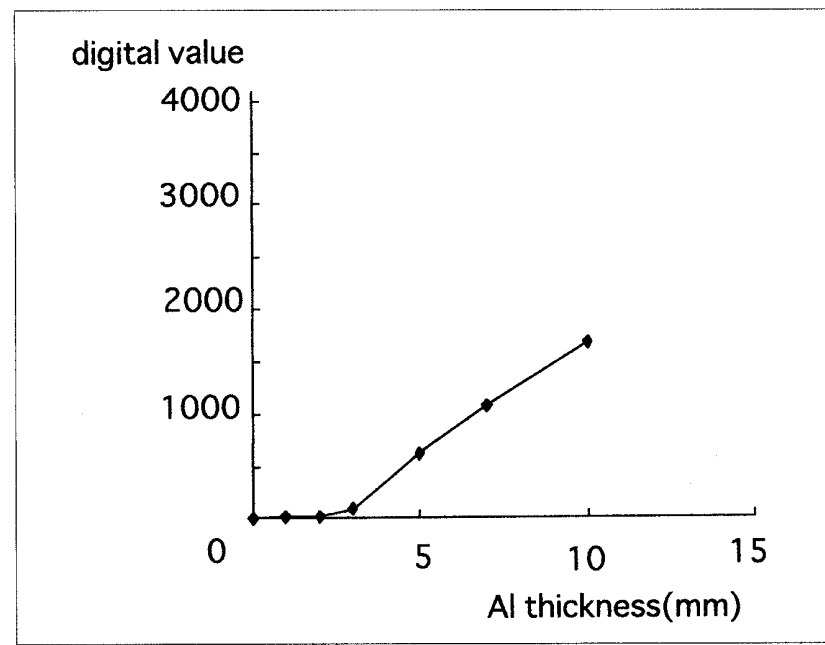

Fig. 3 Relation of aluminum thickness and digital value.

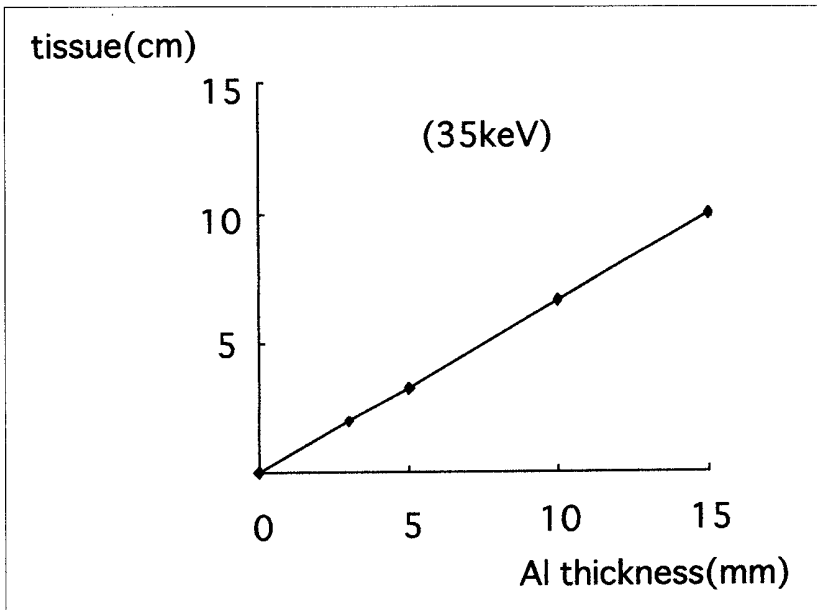

Fig. 5 Relation of aluminum thickness and tissue.

は，その位置まで插入することを考え，線形の楔形状 にした。そしてAlを加工し，高さ $1 \mathrm{~cm}$ (中心部 5 $7 \mathrm{~mm}$ )のFig. 6のような補償フィルタを作成した。

\section{5. 臨床への席用}

\section{5-1 遠隔操作式補償フィルタ}

今回の実験結果から得られた形状の遠隔操作式補償 フィルタ(以下，補償フィルタ)を作成し，左右開きが 可能な電動式遠隔操作方式とした。遠隔操作卓上の絞 りの横で操作し，レスポンスはほぼリアルタイムに挿 入が可能である.Fig. 7に実際の補償フィルタの外観 を示す.

\section{5-2 皮虐線量の検証}

補償フィル夕を挿入したときの線量を調べた．線量 は空気カーマに変換するためW值は33.97を用いた。 同一撮影条件 $(85 \mathrm{kV}, 10 \mathrm{mAs})$ 時，フィル夕をFig. 1 の アクリル+空気側に挿入したとき，B点の線量を測定 


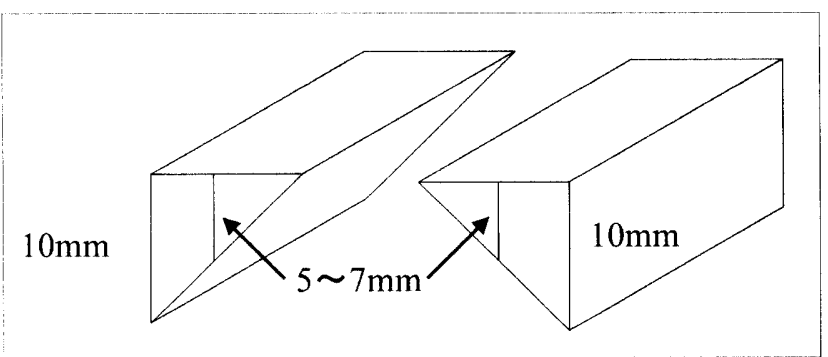

Fig. 6 Shape of aluminum filter.

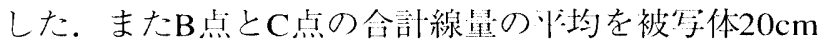

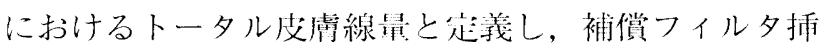

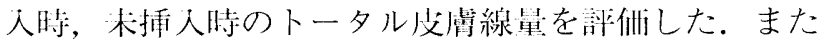

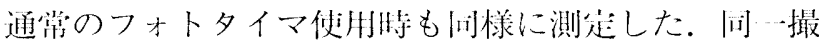
影条件 $(85 \mathrm{kV}, 200 \mathrm{~mA}, 50 \mathrm{msec})$ で，補償フィル夕を Fig.1のアクリル+空父側に抨人したとき，B点の線荲 は0.21mGyであった。トータル支滩線量を補償フィル タの有䲄で比較すると0.88mGyから0.55mGyに約 $40 \%$ 減少した(Fig. 8)。通常，撮影はフォトタイマを䏘い ている。そのためFig. 1で設定した配琶でフォトタイ マ撮影をすると撮影条件が $85 \mathrm{kV}, 100 \mathrm{~mA}, 10 \mathrm{msec}$ $ら 85 \mathrm{kV}, 100 \mathrm{~mA}, 15 \mathrm{msec}$ と 1.5 偣増玑した。しかしト

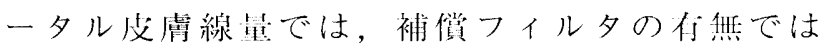
$0.11 \mathrm{mGy}$ と问等の線量であった(Fig.9).

\section{5-3 補償フィルタ使用時の臨床画像}

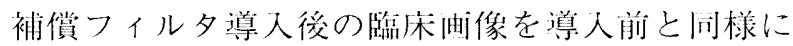
500 唡像を選扒し，digital値のサチュレートが，どの 程度減少したかを検詿した。またフィル夕挿入時と末

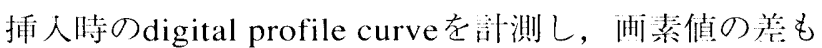
調べた。補償フィル夕導入後に撮影された注腸検柋の 㯺床酒像500西像のうち, digital值がサチュレートし た部分を含む画像は導入咞の74例(約15\%) 加 14例 (約 3\%)に減少した。補償フィルタを1/2まで㨂入した

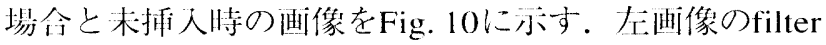

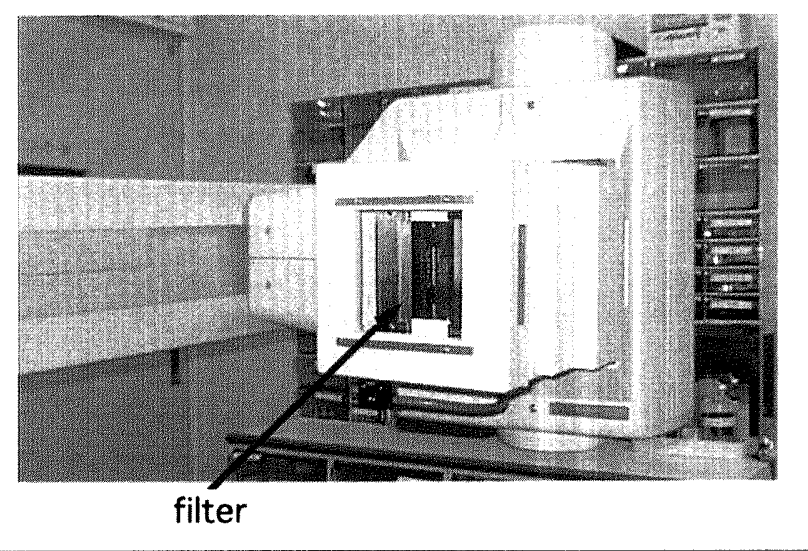

Fig. 7 Aluminum filter.

(ー)の襗がサチュレートされているが，この部分に 補償フィル夕を入れることによって住像に示すよう に两像として認識できている。ささらにig.100中央を 横切る線に沿って計測したdigital值の profile curveを Fig. 11に示す。横軸は画像の幅を表し, 10 bit $(1,024)$ 表小である。そのため，先ほどのサチュレートした部 分は左側から約 250 ピクセルまでを示す。補償フィル 夕を拆人しないと約250ピクセル付近まではdigital值 が2桁であったのが補償フィル夕を挿入することによ って1,000ぐらいまで変化した.

\section{5-4 補償フィルタ使用後の撮影画像数の変化}

補償フィルタ使肞時と未使用時の総撮影画像数の变 化を検討した。補傥フィル夕導入前（1998年11月一 1999作1月)，導人後(1999年5月～1999年7月)に拉 いて阔一医師により撮影をした，それぞれの期間内の 30多の患者をランダムに選択した。その結果総撮影画 像数は，補償フィル夕導入前557画像（1 患者当たり 18.6画像)に刘し，薄入後は534两像（1 患者当たり 17.8 画像)と 1 人当たり約 1 画像の減少となった。

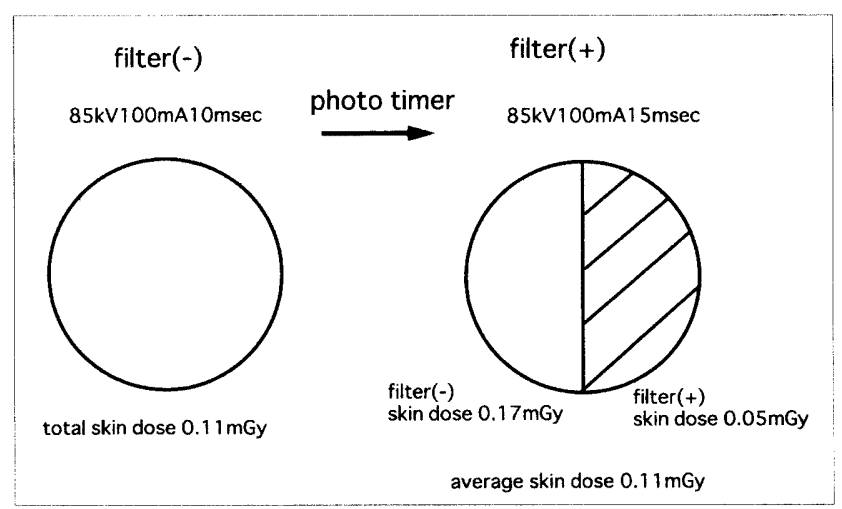

Fig. 9 Change of dose filter and non filter (using photo timer). 


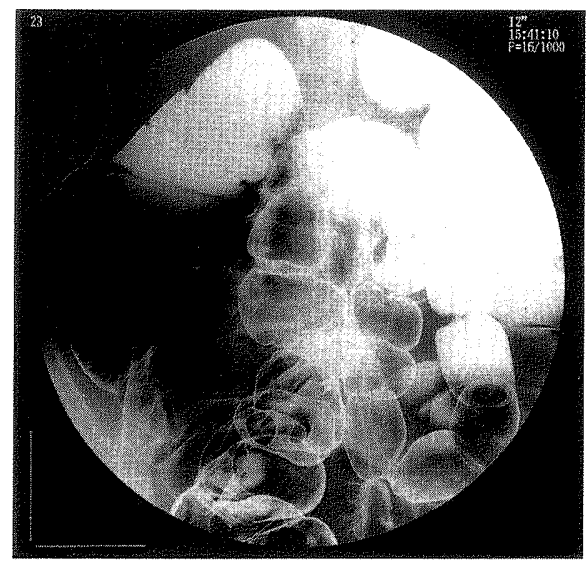

filter(-)

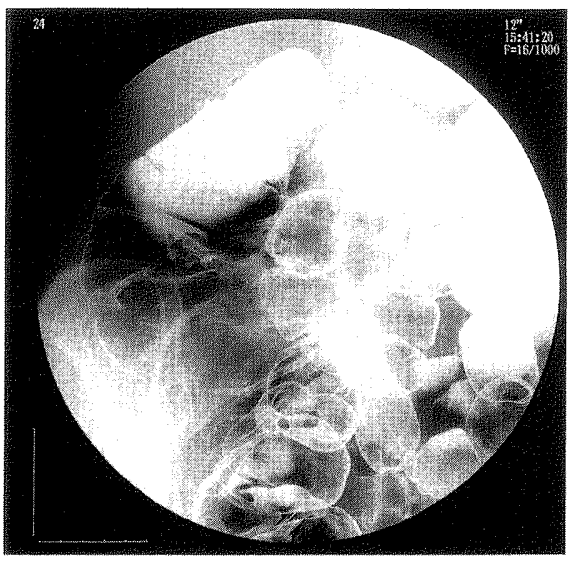

filter(+)

Fig. 10 Clinical image by filter and non-filter.

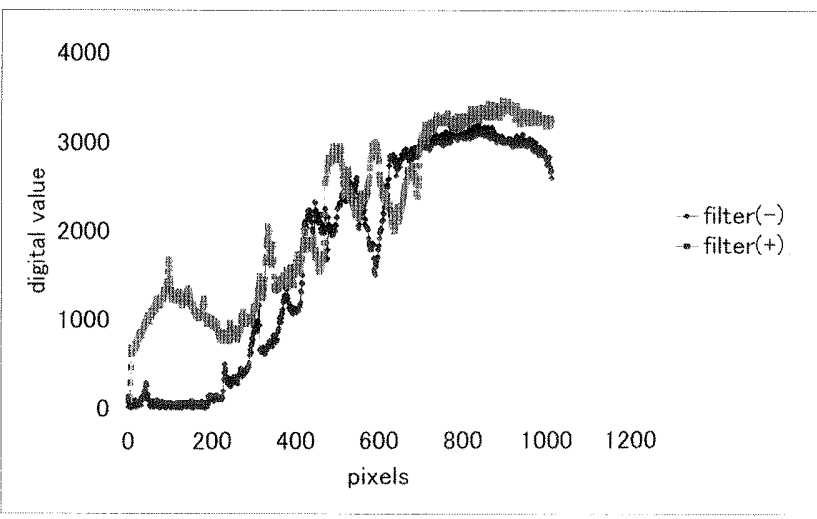

Fig. 11 Digital profile curve by filter and non filter.

\section{6. 考 察}

撮像管とCCDでは明らかにCCDのはうが画質特性 が優れていると石川は述べている。今回のI.I.-DRシ ステムの入出力特性も撮像管タイプよりもCCDのほう がダイナミックレンジに抁いて良い結果を示した。

Fig. 2に示すように光学:系に撮像管(サチコン)とCCD を用いる場合，ダイナミックレンジがdigital值1,000 3,000 の範国では，約 2 倍CCDのほうが優れていた。 しかし現実的に撮像管タイプを使用している施設で は，ダイナミックレンジを少しでも広くするよ大が必 要である。そのためわれわれは，一つの法として今 问の補償フィルタを試みた。

5-3の結果より補償フィル夕導入後, サチュレート した画像が500画像中74例から14例に減少した。この 14例（約 3\%) を詳細に評価すると，腸液等でバリウム の付着が患い姃例に多くみられた。このようなバリウ 厶付着の憲い画像については補償フィル夕を使用して もあまり改善はみられなかった。逆にバリウム付着の 腎い例を除くと，ほぼ全例に改善がみられた。また，
Fig.11に亦すように補償フィル夕を挿入することによ りサチュレートした部分がdigital值1,000ぐらいまで改

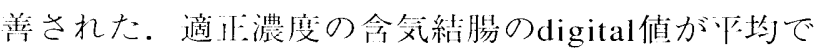

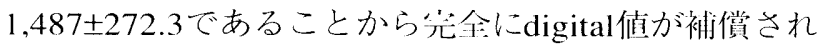
ているわけではないが，この程度であれば㧴像診断が 叮能なレベルまで改善されたと思われる。すなわちこ の補償フィルタを使用することによって，臨休評価に 扮いて有用な町像を得ることを亦している。

また補償フィルタを使用することによって，総醋像 数が減少した。これはdigital值がサチュレートしたこ とによる䑧撮影あるいは追加撮影の減少によるもので ある、特に, I.I.-DRでは撮影した画像がリアルタイ ムにモニタできるため, サチュレートしたときは，再 撮影がすぐに行える。そのためサチュレートしないこ とが再摄影の減少，すなわち被曝線量の減少につなが ると考える。また補償フィルタを使用することによっ てフォトタイマレベルもほぼ分で行えるようになっ た。

一方，問題点は補償フィルタを挿入することによっ て反対側部位の線量が約1.5倍増加してしまうことが 举げられる。しかし, 撮影条件が1.5倍に変化しても 今回の5-2で定義したトータル皮膚表面線量に扔いて は，同等もしくは減少した。すなわちこのフィルタを 使用してもトータルの被曝線量としてはほぼ可等であ ると考える。また，常にフィル夕を画面中央まで抑入 するのではなく，布石端に少量のハレーション領域が 発生する場合は，その位置まで挿入することによって digital值が補償されるため今回の垁験結果のような大 きな線量変化は発生しないと考えられる.

今回は注腸検査で検討を行ったが, 上部消化管造影 にもこのフィルタは有用と考える。 digital值がサチュ レートした部位が明らかに減少したこと, digital pro- 
file curveからdigital值が補償されること, 総画像数の 減少, トータル皮膚線量の減少を考えると上部消化管 造影にもこの補償フィル夕は有用である。

小倉 ${ }^{13)}$ はI.I./TV-DRの場合，入射線量と解像特性と ノイズ特性の間には，複雑な関係があり，これらの特 性を熟知したうえで撮影目的にあったDR装置のパラ メータの設定, 線量, 撮影方法を決定する必要がある と述べている。当院に拈いても装置のダイナミックレ ンジ等, 特性を十分に把握し, 補償フィルタを検討す ることによって臨床的に有用な画像を得ることが可能 となった。

\section{7. 結 語}

補償フィルタを消化管検査に用いることによって従 来, サチュレートのため画像として成立していなかっ た部位が改善された。

撮像管を用いたI.I.-DRシステムで，消化管検査を 行う場合ダイナミックレンジを十分に把握し，補償フ イルタ等の使用によって臨床的に有用な画像を得るこ とが可能となった。

なお本論文の主旨は平成12年 1 月 19 日，第27回関西 バリウムスタディ研究会 (大阪)で発表した。

\section{参考文献}

1) 奥田茂男, 杉野吉則, 今井 裕, 他 : 消化管デジタルラジ オグラフィに扔ける画像処理法の評価。映像情報 (M)，29 (4), 140-144, (1997).

2）栗田幸喜，鈴木 孝, 藤田光雄, 他 : Digital Radiography systemによる消化器診断の実践。映像情報 (M)，30(4), 179-188, (1998).

3）稲本一夫, 小縣裕二, 西岡左智, 他: デジタルX線画像処 理の心用．映像情報 $(M) ， 30(4) ， 189-193 ，(1998)$.

4) 三木 弘, 松本光弘, 祐延良治, 他：DRルーチン検査の 現沉(非血管系)。映像情報（M)，31(4)，136-144， (1999).

5) 加藤英幸, 磯部智子, 越智茂博, 他 : 消化管X線検查にお ける被曝線量の施設間格差の評価法。日放技学誌，55 (7), 655-664, (1999).

6) 江口陽一, 岡田明男, 加賀勇治：100万画素CCDカメラの 画質評価，日放技学誌，52(6)，741-746，(1996).

7) 石川 謙：最近のDR装置の技術的進歩. 日放技学誌，54
(12), 1386-1391, (1998).

8）小林義道，前田 徽: 注腸X線診断用濃度補償フイルタの 試作とその効果(第 1 報)。日放技学誌，43(8)，1161, (1987).

9）塩田政次，奥山恒敏，久保方宏：注腸撮影に扝ける補償つ イルタの作成について，日放技学誌，44(8)，1133， (1988).

10) 前田徹, 小林義道, 中村 仁: 注腸 $\mathrm{X}$ 線診断用濃度補償 フィル夕の試作とその効果 (第2 報)。 日放技学誌，44(8), 1134, (1988).

11) 鈴木 孝, 呇田幸喜, 藤田光雄 : digital radiographyに扔け る付加フィル夕の有用性. 日放技学誌, 54(12)，13731381, (1998).

12）日本放射線技術学会計測分科会編：光子減弱計数データブ ック. (1995).

13) 小倉敏裕：I.I./TV-DRに抢ける被曝線量と物理特性の関 係，日放技学誌，49(12)，2052-2057，(1993).

Fig. 1 測定配置図.

Fig. 2 I.I.-DRシステムの入出力特性.

Fig. 3 Alの厚さとdigital值の関係.

Fig. 4 Alの厚さと皮膚線量の関係.

Fig. $5 \mathrm{Al}$ の厚さと人体組織減弱係数の関係.

Fig. 6 Alフィルタの形状.

Fig. 7 Alフィルタの外観.

Fig. 8 フィル夕挿入, 未扦入による線量の変化(同一撮影条件).

Fig. 9 フィル夕挿入, 未挿入による線量の変化(フォトタイマ使用).

Fig. 10 フィルタ挿入, 未挿入による臨床画像.

Fig. 11 フィルタ挿入, 未挿入によるdigital profile curve. 